\title{
Evaluation of Common Bean Cultivars Resistance to the Bean Common Mosaic Necrosis Virus in Western Kenya
}

\author{
Mangeni Bonphace Collins ${ }^{1, ~ *}$, Ndong'a Millicent ${ }^{1}$, Mukoye Benard ${ }^{2}$, Were Hassan Karakacha ${ }^{1}$ \\ ${ }^{1}$ Department of Biological Sciences, Masinde Muliro University of Science and Technology, Kakamega, Kenya \\ ${ }^{2}$ Department of Biosafety and Phytosanitary, Kenya Plant Health Inspectorate Service (KEPHIS), Kephis Headquarters, Nairobi, Kenya
}

Email address:

bmangeni@mmust.ac.ke (M. B. Collins)

*Corresponding author

To cite this article:

Mangeni Bonphace Collins, Ndong'a Millicent, Mukoye Benard, Were Hassan Karakacha. Evaluation of Common Bean Cultivars Resistance to the Bean Common Mosaic Necrosis Virus in Western Kenya. International Journal of Genetics and Genomics.

Vol. 7, No. 4, 2019, pp. 115-118. doi: 10.11648/j.ijgg.20190704.15

Received: October 1, 2019; Accepted: October 14, 2019; Published: November 15, 2019

\begin{abstract}
The common bean (Phaseolus vulgaris), is a high protein crop and the main legume in the cropping system of western Kenya. Despite its importance, common bean yields are low $(<1.0 \mathrm{t} / \mathrm{ha})$ and declining. Bean Common mosaic virus (BCMV) and Bean common mosaic necrosis virus (BCMNV) are the most common and most destructive and can cause a yield loss as high as $100 \%$. In Kenya, limited cultivars and exotic genotypes with resistance to BCMV and BCMNV strains have been reported. Reports indicate BCMNV being a widespread virus compared to BCMV in western Kenya. This study therefore, sought to screen popular cultivars for resistance to the virus. Sixteen popularly grown bean cultivars together with cowpea (Vigna unguiculata), soybean (Glycine max) and groundnut (Arachis hypogaea) were planted in a green house in a completely randomized block design with three replicates. The plants were inoculated with BCMNV Enzyme Linked Immunosorbent Assay (ELISA) positive isolate at 3-leaf stage. Data was taken weekly for 3 weeks on type of symptoms expressed and number of plants infected. Ten bean cultivars were susceptible, 4 tolerant and 2 resistant. For improved yields of common bean, farmers should be advised to plant certified seeds for all legumes in the cropping system.
\end{abstract}

Keywords: Beans, BCMNV, Resistance, Screening

\section{Introduction}

Western Kenya is one of the food baskets of the country, and a region with about $1 / 3$ of the country's population. The common bean (Phaseolus vulgaris L), is a high protein $(22 \mathrm{~g} / 100 \mathrm{~g})$ crop and the main legume in the cropping system of the region. Small-scale farmers mainly grow the crop. Besides providing food, feed and improving soil fertility, it also improves the incomes of the farmers. Despite its importance, common bean productivity is declining and yields obtained of less than $1.0 \mathrm{t} \mathrm{ha}^{-1}$ are low compared to a production potential of $1400-2000 \mathrm{~kg} \mathrm{ha}^{-1}[1,2]$. This has happened at a time when a greater variety of high protein food sources are needed to ensure food security. Decreasing yields are attributed to poor access to improved seeds, declining soil fertility, drought, and high incidence of pests, diseases and unpredictable weather. One key biotic stress factor that reduces yield is plant viruses, and the common bean is one of the most susceptible legumes to virus infection. The bean common mosaic virus (BCMV) and bean common mosaic necrosis virus (BCMNV) cause significant yield losses and are both seed borne [3]. The two viruses are closely related and belong to the Family Potyviridae, genus Potyvirus, which is the largest of the eight genera currently assigned to the family by the International Committee on Taxonomy of Viruses [4].

The serological relationships of the two viruses (formally serotype A and serotype B and treated as strains of BCMV) was determine and from sequence analysis, it was agreed that they be treated as distinct viruses [5].

$\mathrm{BCMV}$ and BCMNV are the most common and most destructive viruses that infect common beans (Phaseolus vulgaris L.) as well as a range of other cultivated and wild legumes [6]. Yield losses due to BCMV and BCMNV can be as high as $100 \%$ [7]. 
Mottling and malformation of the primary leaves is an indication that the primary infection occurred through seed [8]. Systemically infected plants may have smaller and fewer pods and infected pods may sometimes be covered with small, dark green spots and mature later than uninfected pods.

Breeding for genetic resistance to BCMV and BCMNV is the most durable form of managing the viruses. Bean cultivars possessing the dominant $I$-gene are resistant to BCMV however susceptibility to BCMNV-induce black root disease [9]. Available recessive resistant genes are virus strain-specific, and therefore difficult to breed bean cultivars with a broad resistance to the existing strains of BCMV and BCMNV based on one of these genes alone. Marker-assisted selection can be utilized to pyramid the recessive genes $\left(b c-u, b c-1, b c-1^{2}, b c-2, b c-2^{2}\right.$ and $b c-3$ ), with the dominant $I$-gene in order to provide broad spectrum possible resistance [10].

This study therefore sought to determine the resistance of popular bean cultivars to the disease.

\section{Materials and Methods}

\subsection{Seed Germination and Mechanical Inoculation}

Five seeds from each of the 16 popularly grown bean varieties; and cowpea, soybean, green grams and ground nut were sowed in plastic pots with 3 replicates in a greenhouse.

The inoculum was prepared by grinding BCMNV infected leaves at the rate of $1.0 \mathrm{~g}$ tissue and $10 \mathrm{ml}$ of $0.1 \mathrm{M}$ phosphate buffer, pH7.0 containing $0.2 \%$ sodium sulfite using a chilled pestle and mortar. The test plants were separately inoculated at the 3 leaf stage with BCMNV isolate from western Kenya. Data was taken on type of symptoms expressed by plants and the number of plants showing symptoms weekly for 3 weeks. Systemic infection was determined at the end of second week post inoculation by Double Antibody Sandwich ELISA. Susceptible plants expressed typical symptoms of BCMD. Symptomatic plants positive for BCMNV by DAS ELISA were graded susceptible, symptomatic plants positive for BCMNV graded tolerant while asymptomatic plants negative for BCMNV graded resistant.

\subsection{Enzyme-Linked Immunosorbent Assay (ELISA)}

For all ELISA tests, microtiter plates (Greiner Microlon medium binding) were used and generally volumes for each reactant were kept at $100 \mu \mathrm{l} /$ well.

Between incubations, 3 intensive washing steps each lasting $3 \mathrm{~min}$ were carried out by repeated soaking of the plates in washing buffer for 4 min. Antibodies were provided by Dr. Stephan Winter of DSMZ, Germany.

Leaf tissues of virus-iinnoculated plants were ground 1:10 $(\mathrm{w} / \mathrm{v})$ in sample extraction buffer (PBST $+2 \%$ PVP (Serva PVP-1S polyvinyl pyrrolidone). To detect BCMNV, Double Antibody Sandwich (DAS)-ELISA was conducted essentially as described following manufacturer's instructions [11]. Microtiter plates were coated with BCMV IgG diluted $1: 1000(\mathrm{v} / \mathrm{v})$ in coating buffer $((1.59 \mathrm{~g}$ sodium carbonate
$\left(\mathrm{Na}_{2} \mathrm{CO}_{3}\right), 2.93 \mathrm{~g}$ sodium bicarbonate $\left(\mathrm{NaHCO}_{3}\right), 0.20 \mathrm{~g}$ sodium azide $\left(\mathrm{NaN}_{3}\right)$, Dissolved in $900 \mathrm{ml} \mathrm{H} \mathrm{H}_{2} \mathrm{O}$, adjusted $\mathrm{pH}$ to 9.6 with HCL and made up to 11 ) and incubated for $2 \mathrm{~h}$ at $37^{\circ} \mathrm{C}$. To block, $2 \%$ skimmed milk in PBST $(200 \mu \mathrm{l} /$ well $)$ were added and incubated for $30 \mathrm{~min}$ at $37^{\circ} \mathrm{C}$. The extracts of sap prepared from ground leaf tissues of virus-infected plants $1: 10(\mathrm{w} / \mathrm{v})$ in sample extraction buffer (PBST $+2 \% \mathrm{PVP})$ were added and incubated overnight at $4{ }^{\circ} \mathrm{C}$. Extracts from healthy and of BCMV infected plants were used as negative and positive controls, respectively. IgG alkaline phosphatase conjugate, diluted 1:1000 (v/v) in conjugate buffer (PBST + $2 \%$ PVP $+0.2 \%$ egg albumin (Sigma A-S253)), was added and incubated for $2 \mathrm{~h}$ at $37^{\circ} \mathrm{C}$. The substrate, $p$-Nitrophenyl phosphate diluted $1 \mathrm{mg} / \mathrm{ml}$ in substrate buffer $\left(\mathrm{DEA}+\mathrm{H}_{2} \mathrm{O}\right.$ $+\mathrm{NaN}_{3}$ ) was added and incubated for $1 \mathrm{~h}$ at $37^{\circ} \mathrm{C}$ or until there was colour change. Quantitative measurements of the p-nitrophenol substrate conversion resulting in yellow color were made by determining the absorbance at $405 \mathrm{~nm}$ (A405) in a Biotek ${ }^{\circledR}$ model spectrophotometer (Labsystems Co., Finland). Twice the mean absorbance readings of healthy controls were used as the positive thresholds.

\section{Results}

Sixteen popularly grown common bean cultivars in western Kenya inoculated with BCMNV isolate from western Kenya (Kakamega) in a greenhouse exhibited typical virus symptoms such as leaf mosaic, down ward leaf curl and yellowing as shown on popular variety GLP 2 (Figure 1).

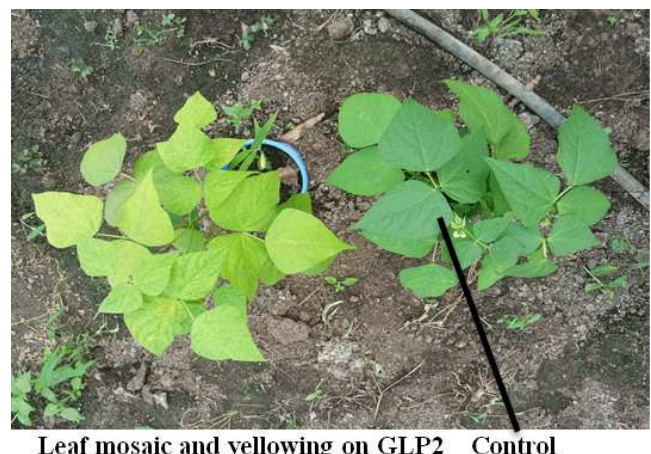

Figure 1. Symptoms expressed on varietal screening for resistance to BCMNV isolate.

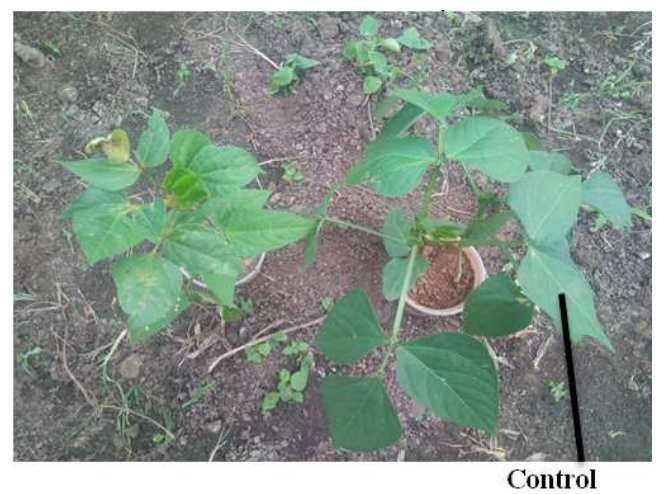

Figure 2. Veinal yellowing and stunting on Cowpea var 'Local' inoculated with $B C M N V$. 
Table 1. Reaction of test plants to BCMNV isolate.

\begin{tabular}{|c|c|c|c|c|c|}
\hline Test plant & Variety & $\begin{array}{l}\text { BCMNV } \\
\text { symptoms }\end{array}$ & $\begin{array}{l}\text { Number of plants } \\
\text { inoculated with BCMNV }\end{array}$ & $\begin{array}{l}\text { Number of symptomatic plants } \\
\text { at } 3 \text { weeks after inoculation }\end{array}$ & $\begin{array}{l}\text { Number of ELISA } \\
\text { positive plants }\end{array}$ \\
\hline Bean & GLP 2 & ST, D & 5 & 5 & 5 \\
\hline Bean & RIL 05 & $\mathrm{D}, \mathrm{M}$ & 5 & 4 & 4 \\
\hline Bean & KK20 & $\mathrm{ST}, \mathrm{M}$ & 5 & 5 & 5 \\
\hline Bean & KK RIL05 & Symptomless & 5 & 0 & 0 \\
\hline Bean & Imbeko & Symptomless & 5 & 0 & 5 \\
\hline Bean & Yellow & M, D & 5 & 5 & 5 \\
\hline Bean & Rosecoco & $\mathrm{Y}, \mathrm{M}$ & 5 & 5 & 5 \\
\hline Bean & Wairimu & M & 5 & 5 & 5 \\
\hline Bean & KK 8 & $\mathrm{M}, \mathrm{Y}$ & 5 & 4 & 3 \\
\hline Bean & Punda & $\mathrm{M}$ & 5 & 5 & 5 \\
\hline Bean & GLPX92 & $\mathrm{Y}, \mathrm{M}$ & 5 & 5 & 5 \\
\hline Bean & KK15 & $\mathrm{Y}$ & 5 & 4 & 4 \\
\hline Bean & KK/RIL5/Red 13 & Symptomless & 5 & 0 & 5 \\
\hline Bean & KK072 & Symptomless & 5 & 0 & 0 \\
\hline Bean & Okwoto & Symptomless & 5 & 0 & 4 \\
\hline Bean & KK RIL05/CAL 194 & Symptomless & 5 & 0 & 3 \\
\hline Groundnut & Red valencia & M & 5 & 2 & 2 \\
\hline Soybean & Nyala & $\mathrm{Y}$ & 5 & 5 & 3 \\
\hline Green Grams & Local & $\mathrm{M}$ & 5 & 4 & 4 \\
\hline Cowpea & Local Cream & $\mathrm{D}$ & 5 & 3 & 3 \\
\hline Cowpea & Local Red & $\mathrm{D}$ & 5 & 4 & 3 \\
\hline Cowpea & Local Black & $\mathrm{D}, \mathrm{Y}$ & 5 & 4 & 3 \\
\hline Cowpea & $\mathrm{K}-80$ & $\mathrm{D}$ & 5 & 3 & 3 \\
\hline Cowpea & KVU 270-1 & $\mathrm{D}$ & 5 & 4 & 4 \\
\hline Cowpea & M66 & $\mathrm{D}$ & 5 & 3 & 3 \\
\hline
\end{tabular}

Key: D-deformed leaves, M-mosaic, Y-yellowing, ST-stunting, C-chlorosis,, (Severity scale:1-Mild, 2- Moderate, 3- Severe)

From Table 1, Sixteen popularly grown common bean cultivars in western Kenya inoculated with BCMNV BG12 isolate from western Kenya (Kakamega) in a greenhouse exhibited typical virus symptoms such as leaf mosaic, down ward leaf curl and yellowing as shown on popular variety GLP 2 (Figure 1). Four bean varieties (Imbeko, KK/RIL5/Red 13, Okwoto, RIL05/CAL 194) were symptomless with BCMNV BG 12 isolate from western Kenya however tested positive for BCMNV by DAS ELISA. Two bean varieties (KK RIL05 and KK 072) were symptomless and negative for BCMNV by DAS ELISA.

Successful infection was determined three weeks post inoculation by both symptomatology and DAS ELISA. Popularly grown grain legumes, groundnut cv 'Red Valencia, soybean cv 'Nyala', greengrams cv 'Local', cowpea cv 'Local cream', 'Local black', 'K-80', 'KVU 270-1' and 'M66' screened for host range expressed distinct symptoms of stunted growth, shortened internodes, thickened stems, necrosis, dwarfism with bushy appearance, yellowing with chlorosis lesions, mixed mosaic, reduced leaf area with twisted and distorted leaves curling downwards and upwards (Figure 2).

\section{Discussion}

BCMNV presence in western Kenya as detected by serology concurs with earlier studies by Mutuku et al., (2018)
[12]. BCMNV increase the risks of farming as a livelihood strategy or a commercial enterprise by decreasing agricultural yields, raising production costs and limiting marketability of food and feed legumes [13]. Despite the importance of beans, virus effects are largely unrecognised by most farmers from western Kenya. Seed borne viruses, have great potential to reduce bean growth and yield because the plant germinates already infected [14]. It has been reported that even low seed borne transmission rates of viruses may be sufficient to cause severe disease epidemics when combined with efficient spread by vectors to susceptible crops [15]. Several virus control measures have been examined and are in use but host plant resistance seems the most economical, practical and environmentally friendly option [16]. Because BCMNV and BCMV detected by serology were in mixed infections, breeding for single virus resistance may not be of much help. It is therefore worth the effort to breed for multiple-virus resistance as suggested by Orawu (2013) to counter this problem [17]. High levels of viral diseases have been revealed by our studies in bean crops in all growing counties of Western Kenya. This is because, most of the viruses are seedborne and the climate favours virus vector insects (aphids) coupled by the fact that farmers plant their own seen not certified for virus freedom. The results indicate that seeds are the major source of virus infection, a finding supported by earlier report that observed that infected seed increased virus incidence by $25 \%$ in 
groundnuts compared to certified seed [18]. This is laudable because insects spread the virus from some source, which if absent there will be no virus.

\section{Conclusion}

This study shows most popular bean varieties grown in western Kenya are all susceptible to BCMNV when inoculated mechanically. Other popular legume varieties such as those of cowpea, groundnut and greengrams grown in western Kenya are also susceptible to BCMNV infection and therefore potential hosts for the virus. Use of virus resistant variety is the best alternative and durable method to alleviate occurrence of BCMD. Identification of BCMD resistant legume genotypes is very much essential and screening to identify stable resistance source. However, the nature of disease resistance being complex makes the identification of resistant and susceptible lines cumbersome through conventional screening techniques and therefore DNA based molecular markers such as RAPD, RFLP, AFLP and SSR will be useful to assess genetic diversity of genotypes.

\section{Acknowledgements}

This study was financially supported by postgraduate research grant from National Research Fund Kenya (NRF, 2017/2018 FY; SCP/G/04/2015).

\section{References}

[1] Kayondo, S. I., Rubaihayo, P. R., Ntare, B. R., Gibson, P. I., Edema, R., Ozimati, A and Okello, D. K. 2014. Genetics of resistance to groundnut rosette virus disease: Afri Crop Sci 22: 21-29.

[2] Katungi, E., Farrow, A., Chianu, J., Sperling. L and Beebe S. 2009. Common bean in Eastern and Southern Africa: a situation and outlook analysis. CIAT.

[3] Chiquito-Almanza, E.1., Acosta-Gallegos, J. A., GarcíaÁlvarez, N, C., Garrido-Ramírez, E. R., Montero-Tavera, V., Guevara-Olvera, L. 2017. Simultaneous Detection of Both RNA and DNA Viruses Infecting Dry Bean and Occurrence of Mixed Infections by BGYMV, BCMV and BCMNV in the Central-West Region of Mexico, 30: 9.

[4] ICTV. 2013. Virus taxonomy: release. http://www.ictvonline.org/virusTaxonomy.asp. (Accessed 11 March 2019).

[5] Vetten, H., Lesemann, D. E and Maiss, E. 1992. Serotype A and $\mathrm{B}$ strains of bean common mosaic virus are two distinct potyviruses. Arch Virol 5: 415-431.
[6] Morales, F. J. Common beans. In G. Loebenstein \& J. P. Carr (Eds.), Natural resistance mechanisms of plants to viruses. The Netherlands: Springer. 2006.

[7] Li, Y. Q., Liu, Z. P., Yang, Y. S., Zhao, B., Fan, Z. F and Wan, P. 2014. First report of Bean common mosaic virus infecting Azuki bean (Vigna angularis Ohwi \& Ohashi) in China. Plant Dis 98: 10-17.

[8] Bos, L. 1971. Bean common mosaic virus. Descriptions of Plant Viruses 73.

[9] Worrall, E. A., Wamonje, F, O., Mukeshimana, G., Harvey, J. J. W., Carr, J. P and Mitter, N. 2015. Bean Common Mosaic Virus and Bean Common Mosaic Necrosis Virus: Relationships, Biology, and Prospects for Control. Adva Virus Res 93: 1-46.

[10] Pasev, G., Kostova, D and Sofkova, S. 2014. Identification of genes for resistance to Bean common mosaic virus and Bean common mosaic necrosis virus in snap bean (Phaseolus vulgaris L.) breeding lines using conventional and molecular methods. J Phytopathol 162: 19-25.

[11] Were, H. K., Winter, S and Maiss, E. 2004. Viruses infecting cassava in Kenya. Plant Dis. 88: 17-22.

[12] Mutuku, J, M., Wamonje, F. o., Mukeshimana, G., Njuguna, J.,, Wamalwa, M., Seung-Kook Choi., Tungadi, T., Djikeng, A., Kelly, K., Entfellner, J. B. D., Ghimire, S. R., Mignouna, H. D., Carr, J. P and Harvey, J. J. W. 2018. Metagenomic Analysis of Plant Virus Occurrence in Common Bean (Phaseolus vulgaris) in Central Kenya. Front Microbiol. 9: 29-39.

[13] Akinyemi, I. A., Wang, F., Zhou, B., Qi, S and Wu, Q. 2016. Ecogenomic survey of plant viruses infecting Tobacco by Next generation sequencing. Virol 13: 181

[14] Marcenaro, D and Valkonen, J. P. T. 2016. Seedborne pathogenic fungi in common bean (Phaseolus vulgaris cv. INTA Rojo) in Nicaragua. PLoS ONE.; 11.

[15] Johansen, E., Edwards, M. C and Hampton, R. O. 1994. Seed transmission of viruses: current perspectives. Annu Rev Phytopathol. 32: 363-386.

[16] Bashir, M and Hampton, R. O. 1996. Sources of genetic resistance in cowpea (Vigna unguiculata (L.) Walp.) to cowpea aphidborne mosaic potyvirus. Eur J Plant Pathol 102: 411-419.

[17] Orawu, M., Melis, R., Laing, M and Derera, J. 2013. Genetic inheritance of resistance to cowpea aphid-borne mosaic virus in cowpea. Euphytica 189: 191-201 DOI 10.1007/s10681012-0756-3.

[18] Demski, J. W.1975. Source and spread of peanut mottle virus in soybean and peanut. Phytopathology 65: 917-920. 